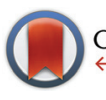

CrossMark click for updates

Cite this: Org. Biomol. Chem., 2016, 14, 4436

Received 21st March 2016

Accepted 11th April 2016

DOI: 10.1039/c6ob00609d

www.rsc.org/obc

\section{Synthesis of new C-5-triazolyl-functionalized thymidine analogs and their ability to engage in aromatic stacking in DNA : DNA and DNA : RNA duplexes $\uparrow$}

\author{
Mick Hornum, Alevtina Djukina, Ann-Katrin Sassnau and Poul Nielsen*
}

1-Phenyl-1,2,3-triazole scaffolds on the 5-position of pyrimidine nucleosides have previously shown to enhance nuclease stability and increase the duplex thermal stability $\left(T_{m}\right)$ by engaging in duplex stacking interactions. In this study, we have introduced two new derivatives of this scaffold in DNA: DNA and DNA : RNA duplexes in order to explore the thermal effects of (1) using a 1,5-triazole instead of the usual 1,4-triazole, and (2) replacing the apolar phenyl substituent with a polar uracil-5-yl substituent.

\section{Introduction}

The 5-position of pyrimidines has long been a popular site for fine-tuning the physical and biological properties of oligonucleotides and nucleic acid duplexes. ${ }^{1}$ In addition to their well-defined location in the major groove of duplexes, 5 -substituents are known to influence the stacking of nucleobases in duplexes. For instance, a 5-methyl group increases the molecular polarizability of the pyrimidine, thereby increasing the base stacking, ${ }^{2}$ which is widely used in e.g. antisense therapeutics for increasing the affinity of oligonucleotides toward complementary RNA. ${ }^{3}$ The stacking interactions can be further augmented by employing small 5-alkynyl or 5-heteroaryl substituents, such as 5-propyn-1-yl ${ }^{4}$ and 5-thiazol-2-yl. ${ }^{5}$

Elaboration of these structures has enabled us to design 5-triazole-substituted pyrimidine nucleosides, which were shown to provide dramatic improvements in duplex stability. ${ }^{6}$ In addition, oligodeoxynucleotides bearing these monomers maintain high base-pairing specificity, ${ }^{6,7}$ show improved stability toward $3^{\prime}$-exonucleoases ${ }^{7 b}$ and compatibility with RNase $\mathrm{H}$ enzymes, ${ }^{8}$ making these 5 -triazole-substituted pyrimidine building blocks strong candidates in antisense therapeutics. Starting from 5-ethynyl pyrimidine nucleosides, ${ }^{9}$ the copper(I)catalyzed alkyne-azide cycloaddition ${ }^{10}$ (CuAAC) has allowed us to employ an arsenal of different aliphatic or aromatic azides to yield an analogous set of 5-(1-substituted-1,2,3-triazole)functionalized nucleoside products with relative ease. ${ }^{6,711}$ The

Nucleic Acid Center, Department of Physics, Chemistry \& Pharmacy, University of Southern Denmark, Campusvej 55, DK-5230 Odense, Denmark. E-mail:pouln@sdu.dk

$\dagger$ Electronic supplementary information (ESI) available: Selected NMR spectra and MALDI-TOF of oligonucleotides. See DOI: 10.1039/c6ob00609d studies showed that monomer $\mathbf{X}$ (Fig. 1) with a 1-phenyltriazol4 -yl moiety ${ }^{6,7 a}$ stacks more strongly than the triazole alone, and different small substituents on the phenyl group can enhance stacking interactions slightly. ${ }^{7 a, 11}$ While single incorporations of these monomers generally destabilize DNA : DNA and DNA : RNA duplexes, due to their displacement of the otherwise well-ordered water molecules within the major groove of the duplex, multiple incorporations evoke thermostabilizing effects that more than compensates for the solvation penalty, suggesting that the phenyltriazoles stack efficiently in the major groove.

Although aromatic stacking provides the dominating contribution to the overall stability of the nucleic acid duplexes in general, ${ }^{12}$ the nature of this interaction is not well understood. It is now well-established that $\pi-\pi$ stacking is not precisely described by the mere interaction of $\pi$ clouds above and below the planes of neighbouring aromatic rings. ${ }^{13}$ Both enthalpydriven electrostatic interactions and van der Waals dispersion forces, as well as entropy-driven solvophobic effects have been suggested as the major components behind the stacking in aqueous media, ${ }^{14}$ but no clear unified picture regarding the relative importance of these basic physical contributions exists. ${ }^{12}$

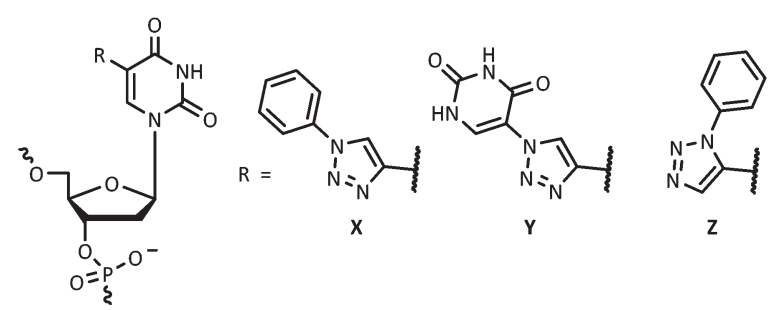

Fig. 1 Structures of monomers $\mathrm{X}, \mathrm{Y}$ and $\mathrm{Z}$. 
While it is accepted that stacking correlates with the surface area, there is no satisfactory answer to the correlation between other physical properties such as hydrophobicity or geometry.

In the present study, we have introduced more radical changes to our 1-phenyl-1,2,3-triazole scaffold in order to investigate the scope of these stacking interactions in the aqueous media of the major groove. To this end, we hereby report our findings with monomers $\mathbf{Y}$ and $\mathbf{Z}$ (Fig. 1), where we have explored the thermostabilizing and structural consequences of, respectively, increasing the hydrophilicity of the 5 -triazole substituent significantly, and altering the substitution geometry of the triazole ring (1,4- vs. 1,5-disubstituted triazole).

Monomer Y features a uracil-triazole moiety on the 5-position and is hereby designed to be a simple hydrophilic version of the traditional phenyl-triazole moiety of monomer $\mathbf{X}$. Being roughly the same size as the phenyl substituent, the uracil substituent also possesses very large bond moments and is less polarizable, and so these two monomers are expected to stack energetically differently in the major groove. The other new monomer, $\mathbf{Z}$, is designed to be a geometric analog of monomer $\mathbf{X}$, where the phenyl substituent is projected nonlinearly into the major groove as opposed to monomer $\mathbf{X}$. This bent structure is interesting in terms of understanding what geometry of the 5-substituent is most suitable for engaging in stacking interactions in the major groove. While these two structures differ only in their substitution pattern of the 1,2,3triazole ring, we speculated that their slightly different vectors of expanding into the major groove could exert diametrically opposed effects on the duplex structure.

\section{Results}

\section{Chemical synthesis}

The new monomers $\mathbf{Y}$ and $\mathbf{Z}$ were successfully incorporated into oligodeoxynucleotides on an automated solid-phase DNA synthesizer using the nucleoside phosphoramidites $\mathbf{3}$ and $\mathbf{8}$ (Scheme 1) when activated by $1 H$-tetrazole. The oligonucleotide sequences chosen for the present study is a T-rich 9-mer sequence (5'-dGTGTTTTGC) with one to four central incorporations of $\mathbf{Y}$ and $\mathbf{Z}$ in accordance with some of our previous studies with $\mathbf{X} .{ }^{6,7 a, 11}$

The core structure of monomer $\mathbf{Y}$ was successfully obtained by treating the well-known 5-ethynyl-5'-O-DMT-2'-deoxyuridine $^{15}$ (1) with freshly synthesized 5-azidouracil ${ }^{16}$ under copper(I) catalysis, similar to our protocol for synthesis of $\mathbf{X} .^{17}$ This afforded nucleoside 2 in $75 \%$ yield. The structure of 2 was carefully identified by means of 2D HSQC, COSY and HMBC in order to confirm the precise structure of the 5-substituent. Subsequent phosphitylation of nucleoside 2 under standard conditions gave phosphoramidite 3 . For the synthesis of monomer $\mathbf{Z}$, the 1,5-disubstituted triazole scaffold (nucleoside 5) was obtained by treating acetyl-protected 5-ethynyl-2'-deoxyuridine (4) with phenylazide under a cooperative effect of microwave activation and ruthenium catalysis ${ }^{18}$ analogous to a procedure used by Agrofoglio and co-workers ${ }^{19}$ for the regio-
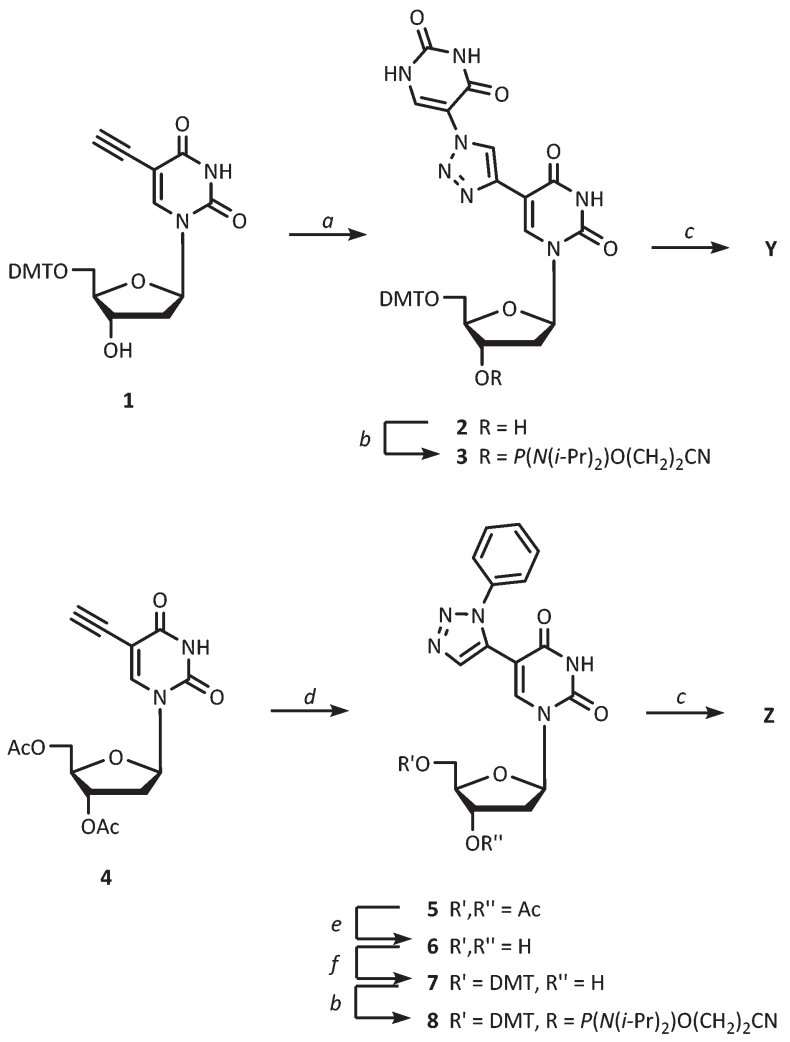

Scheme 1 Reagents and conditions: (a) 5-azidouracil, $\mathrm{Na}$ ascorbate, $\mathrm{CuSO}_{4}, \mathrm{H}_{2} \mathrm{O}, t-\mathrm{BuOH}$, rt, $75 \%$; (b) $\mathrm{P}\left(\mathrm{N}(\mathrm{i}-\mathrm{Pr})_{2}\right) \mathrm{O}\left(\mathrm{CH}_{2}\right)_{2} \mathrm{CN}$, diisopropylammonium tetrazolide, $\mathrm{CH}_{2} \mathrm{Cl}_{2}, \mathrm{rt}, 71 \% 3,50 \%$ 8; (c) automated DNA synthesis; (d) phenylazide, $\mathrm{Cp} * \mathrm{RuCl}\left(\mathrm{PPh}_{3}\right)_{2}, \mathrm{MTBE}, \mathrm{THF}, \mathrm{MW}, 100{ }^{\circ} \mathrm{C}$; $80 \%$; (e) $\mathrm{NH}_{3}, \mathrm{MeOH}, \mathrm{rt}, 67 \%$; (f) DMTCl, pyridine, $57 \%$.

selective generation of similar 1,5-disubstituted 1,2,3-triazolonucleosides. Small amounts of the formed 1,4-regioisomer was removed by chromatography, and nucleoside $\mathbf{5}$ was isolated in $80 \%$ yield. Although this reaction type generally accepts unprotected nucleosides, ${ }^{18 b}$ we observed that protecting groups were necessary in order to minimize unspecific side reactions. Phosphoramidite $\mathbf{8}$ was obtained in good yield after deacetylation (to form 6), selective 5 '-O-tritylation (to form 7 ) and finally 3'-O-phosphitylation; all under standard conditions.

\section{UV spectroscopy}

The oligonucleotides were mixed in a phosphate buffered saline solution with the complementary DNA and RNA sequences using $1.5 \mu \mathrm{M}$ of each strand. The melting temperatures $\left(T_{\mathrm{m}}\right)$ of the resulting DNA : DNA and DNA : RNA duplexes (Table 1) were determined by means of a UV spectrometer using a Peltier Temperature Programmer. The $T_{\mathrm{m}}$ values were derived from the first derivatives of the melting curves recorded at $260 \mathrm{~nm}$ (as duplicate readings that agreed within $\pm 0.5 \%)$.

As shown in Table 1, a single incorporation of $\mathbf{Y}$ in the centre of DNA : DNA destabilizes the duplex by $-1.7^{\circ} \mathrm{C}$ (entry $6)$, which is, however, significantly less than that for $\mathbf{X}\left(\Delta T_{\mathrm{m}}=\right.$ $-5.0^{\circ} \mathrm{C}$, entry 2), suggesting that the polar profile of $\mathbf{Y}$ is much 
Table 1 Hybridization data for the synthesized oligonucleotides against matched DNA and RNA strands

\begin{tabular}{llll}
\hline & & \multicolumn{2}{l}{$T_{\mathrm{m}}{ }^{a}\left(\Delta T_{\mathrm{m}} / \mathrm{mod}.\right)\left[{ }^{\circ} \mathrm{C}\right]$} \\
\cline { 3 - 4 }$\#$ & Sequence & Compl. DNA & Compl. RNA \\
\hline 1 & 5'-dGTG TTT TGC & 33.0 & 31.0 \\
& & & \\
2 & $5^{\prime}$-dGTG TXT TGC & $28.0^{b}(-5.0)$ & $29.0^{b}(-2.0)$ \\
3 & 5'-dGTG TXX TGC & $30.5^{c}(-1.5)$ & $37.5^{c}(+3.3)$ \\
4 & 5'-dGTG XXX TGC & $30.0^{c}(-1.0)$ & $43.0^{c}(+4.0)$ \\
5 & 5'-dGTG XXX XGC & $32.0^{b}(-0.3)$ & $51.5^{b}(+5.1)$ \\
& & & \\
6 & 5'-dGTG TYT TGC & $31.3(-1.7)$ & $29.9(-1.1)$ \\
7 & 5'-dGTG TYY TGC & $32.2(-0.4)$ & $36.2(+2.6)$ \\
8 & 5'-dGTG YYY TGC & $35.0(+0.7)$ & $43.1(+4.0)$ \\
9 & 5'-dGTG YYY YGC & $38.3(+1.3)$ & $52.0(+5.2)$ \\
& & & \\
10 & 5'-dGTG TZT TGC & $19.7(-13.3)$ & n.t. ${ }^{d}$ \\
11 & 5'-dGTG TZZ TGC & $19.0(-7.0)$ & n.t. ${ }^{d}$ \\
12 & 5'-dGTG ZZZ TGC & n.t. ${ }^{d}$ & n.t.
\end{tabular}

${ }^{a}$ Melting temperatures $\left(T_{\mathrm{m}}\right)$ are derived from the maxima of the first derivatives of the absorbance $(260 \mathrm{~nm})$ vs. temperature curves. The samples contained $1.5 \mu \mathrm{M}$ of each oligonucleotide and $1.5 \mu \mathrm{M}$ of complementary DNA or RNA (5'-GCAAAACAC) in PBS buffer $(2.5 \mathrm{mM}$ $\mathrm{Na}_{2} \mathrm{HPO}_{4}, 5.0 \mathrm{mM} \mathrm{NaH} \mathrm{PO}_{4}, 100 \mathrm{mM} \mathrm{NaCl}, 0.1 \mathrm{mM}$ EDTA, pH 7). Values in brackets show changes in the $T_{\mathrm{m}}$ values per modification compared to the unmodified duplex. ${ }^{b}$ Value taken from ref. $6 .{ }^{c}$ Value taken from ref. $7 a .{ }^{d}$ No clear transition was observed.

better accommodated in the major groove than the non-polar residue of $\mathbf{X}$. As expected, the degree of destabilization is compensated once several residues are installed: the DNA: DNA duplexes featuring three and four consecutive $\mathbf{Y}$ residues are thermally stabilized by $+2.0{ }^{\circ} \mathrm{C}$ (entry 8 ) and $+5.3{ }^{\circ} \mathrm{C}$ (entry 9 ), respectively, which is significantly better than what is achieved with $3 \times \mathbf{X}\left(-3.0^{\circ} \mathrm{C}\right.$, entry 3$)$ and $4 \times \mathbf{X}\left(-1.0^{\circ} \mathrm{C}\right.$, entry 4$)$. While the stacking between two $\mathbf{X}$ residues (entry 2 ) appears slightly better than between two $\mathbf{Y}$ residues (entry 7), the favorable stacking of multiple $\mathbf{Y}$ residues seems more consistent and, in general, better than multiple $\mathbf{X}$ residues (Fig. 2).

For a single incorporation of monomer $\mathbf{Z}$ in the DNA : DNA duplex (entry 10), a relatively weak melting transition was

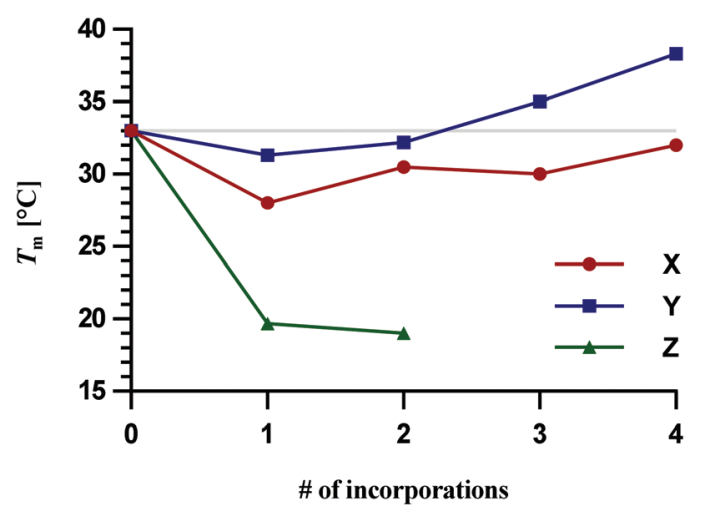

Fig. 2 Graphical illustration of correlation between $T_{m}$ and the number of incorporations of $\mathbf{X}$ (red), $\mathbf{Y}$ (blue) and $\mathbf{Z}$ (green) in the DNA:DNA duplexes. observed at $19.7^{\circ} \mathrm{C}$, which represents a remarkable destabilization of $-13.3^{\circ} \mathrm{C}$ compared to the unmodified duplexes (entry 1 ) and $-8.3{ }^{\circ} \mathrm{C}$ relative to that of its regioisomer $\mathbf{X}$ (entry 2). Similarly, the duplex bearing two $\mathbf{Z}$ residues was destabilized by $-14.0{ }^{\circ} \mathrm{C}$ (or $-7.0{ }^{\circ} \mathrm{C}$ per mod., entry 11 ), however, the melting transition for this entry was extraordinarily weak. No clear melting was observed for the entry with $3 \times \mathbf{Z}$ (entry 12), which is an indication of either the dim hyperchromicity exerted by the presence of $\mathbf{Z}$ or the lack of any hybridization such that no denaturation occurs. In the study involving targeting complementary RNA, all entries with $\mathbf{Z}$ showed no clear melting transitions; even when measured down to $5{ }^{\circ} \mathrm{C}$ and at an increased salt concentration. Monomer $\mathbf{Z}$ was found to cause a slight redshift of the absorption maximum, but also no clear melting was detected when recorded at $\lambda_{\max }=$ $252 \mathrm{~nm}$.

In the case of $\mathbf{Y}$ in the DNA : RNA study, an initial destabilization of $-1.1{ }^{\circ} \mathrm{C}$ was observed for the initial incorporation (entry 6) compared to the native duplex, but with each additional $\mathbf{Y}$ residue, the melting temperature increases almost linearly with a gradient of roughly $+7{ }^{\circ} \mathrm{C}$ per incorporation (entries 7-9). Therefore, it follows the exact same tendency as $\mathbf{X}$, and their thermostabilizing effects on DNA : RNA duplexes are indeed almost equivalent as evident from Fig. 3.

The high-affinity targeting of complementary RNA for oligonucleotides containing four incorporations of $\mathbf{Y}$ allowed us to study its base-pairing specificity toward mismatched RNA strands (Table 2). By introducing a Y : U mismatched base pair in the centre of the duplex (entry 2), we found that the $T_{\mathrm{m}}$ plummeted by $-21.9{ }^{\circ} \mathrm{C}$ relative to the fully complementary DNA : RNA duplex, indicating that the $\mathrm{A} \rightarrow \mathrm{U}$ mutation is very well-discriminated similar to what was observed for the corresponding $\mathrm{X}: \mathrm{U}$ mismatch (entry $1, \Delta T_{\mathrm{m}}=-20.5^{\circ} \mathrm{C}$ ). A central Y : C mispair was also found to be very well-discriminated $\left(\Delta T_{\mathrm{m}}=-18.0{ }^{\circ} \mathrm{C}\right)$, albeit not as exceptional as the corresponding $\mathbf{X}: \mathrm{C}$ mismatch $\left(\Delta T_{\mathrm{m}}=-27.5^{\circ} \mathrm{C}\right)$. Traditionally, the $\mathrm{A} \rightarrow \mathrm{G}$ transition is the least discriminated mutation $\left(\Delta T_{\mathrm{m}}=\right.$ $-8.8{ }^{\circ} \mathrm{C}$ ) as the $\mathbf{Y}: \mathrm{G}$ mispair presumably adopts a wobble configuration.

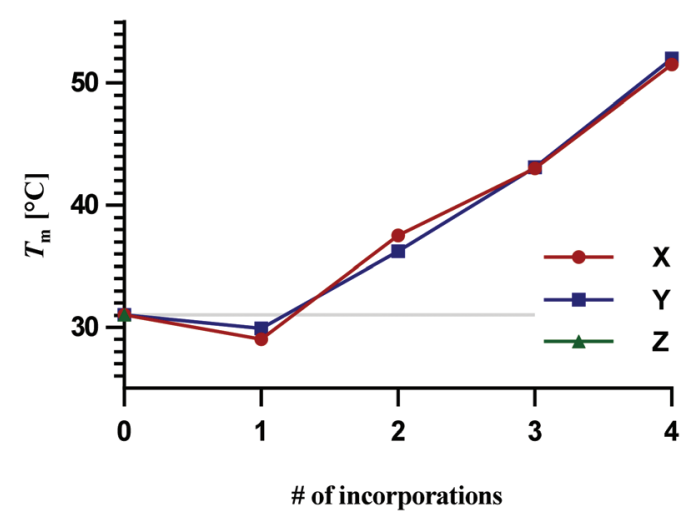

Fig. 3 Graphical illustration of the correlation between $T_{m}$ and the number of incorporations of $X$ (red), $Y$ (blue) and $Z$ (green; no entries) in the DNA : RNA duplexes. 
Table 2 Hybridization data for the synthesized oligonucleotides against mismatched RNA

\begin{tabular}{|c|c|c|c|c|c|}
\hline \multirow[b]{2}{*}{ \# } & \multirow[b]{2}{*}{ Sequences $\left[{ }^{*}\right]=$} & \multicolumn{4}{|c|}{$T_{\mathrm{m}}{ }^{a}\left(\Delta T_{\mathrm{m}}\right)\left[{ }^{\circ} \mathrm{C}\right]$} \\
\hline & & $\mathrm{A}$ & $\mathrm{U}$ & G & $\mathrm{C}$ \\
\hline 1 & $\begin{array}{l}5^{\prime} \text {-dGTG XXX XGC } \\
\left.3^{\prime} \text {-rCAC A[ }{ }^{*}\right] \text { A ACG }\end{array}$ & $51.5^{b}$ & $31.0^{b}(-20.5)$ & $42.0^{b}(-9.5)$ & $24.0^{b}(-27.5)$ \\
\hline 2 & $\begin{array}{l}5^{\prime} \text {-dGTG YYY YGC } \\
\left.3^{\prime} \text {-rCAC A[* }{ }^{*}\right] \text { A ACG }\end{array}$ & 52.0 & $30.1(-21.9)$ & $43.2(-8.8)$ & $34.0(-18.0)$ \\
\hline
\end{tabular}

${ }^{a}$ Melting temperatures $\left(T_{\mathrm{m}}\right)$ are derived from the maxima of the first derivatives of the absorbance $(260 \mathrm{~nm})$ vs. temperature curves. The samples contained $1.5 \mu \mathrm{M}$ of each oligonucleotide strands in PBS buffer $\left(2.5 \mathrm{mM} \mathrm{Na}_{2} \mathrm{HPO}_{4}, 5.0 \mathrm{mM} \mathrm{NaH} \mathrm{PO}_{4}, 100 \mathrm{mM} \mathrm{NaCl}, 0.1 \mathrm{mM}\right.$ EDTA, pH 7). Values in brackets show changes in the $T_{\mathrm{m}}$ values compared to the duplexes with $\left[{ }^{*}\right]=\mathrm{A} .{ }^{b}$ This value is taken from ref. 6 .

\section{CD spectroscopy}

In order to investigate the overall structural changes imposed by $\mathbf{Y}$ and $\mathbf{Z}$, the unmodified and modified duplexes were evaluated with circular dichroism (CD) spectroscopy. The CD spectra were recorded in the $200-350 \mathrm{~nm}$ range using $1.5 \mu \mathrm{M}$ concentrations of each strand dissolved in PBS buffer. A static temperature of $10^{\circ} \mathrm{C}$ was used for duplexes containing $\mathbf{Y}$, and $5{ }^{\circ} \mathrm{C}$ was used for duplexes containing $\mathbf{Z}$, in order to ensure that most of the oligonucleotides were in the hybridized form. The CD spectra of duplexes containing $\mathbf{Y}$ and $\mathbf{Z}$ are shown in Fig. 4, and the CD spectra of duplexes containing $\mathbf{X}$ can be found in ref. 6 and 7a. The CD spectrum of the single-stranded RNA (3'-rCACAAAACG) is also included in the DNA: RNA figures, since this oligonucleotide was found to show large Cotton effects on its own. The CD bands arising from the single-stranded DNA strands were found to be completely negligible, and are not included.

As expected, the unmodified DNA: DNA duplex adopts bands that are typical of B-type helix such as CD maxima at $\sim 285$ and $\sim 220 \mathrm{~nm}, \mathrm{CD}$ minimum at $\sim 250 \mathrm{~nm}$, and a clear cross-over point at the absorption maxima $\sim 260 \mathrm{~nm} .{ }^{20}$ Upon a single incorporation of $\mathbf{Y}$ (Fig. 4A, entry 6), no significant change in the CD curve was observed. However, upon introducing multiple $\mathbf{Y}$ residues (entries 7-9), a progressive transition toward the A-type helix was observed, epitomized by a distinct blue shift of the CD maximum at $285 \mathrm{~nm}$ and an intensifying negative band at $210 \mathrm{~nm}$, which are the spectral features of A-type helices. In addition, new bands evolve at $\sim 310$ and $\sim 235 \mathrm{~nm}$, reflecting local geometry changes in the structures that are neither typical of A- nor B-type helices, but possibly arise from the stacking uracil-triazole moieties. While the bands at $\sim 235 \mathrm{~nm}$ were also present upon multiple incorporations of $\mathbf{X}$, it is much more intense for $\mathbf{Y}$ than $\mathbf{Z}$, and the
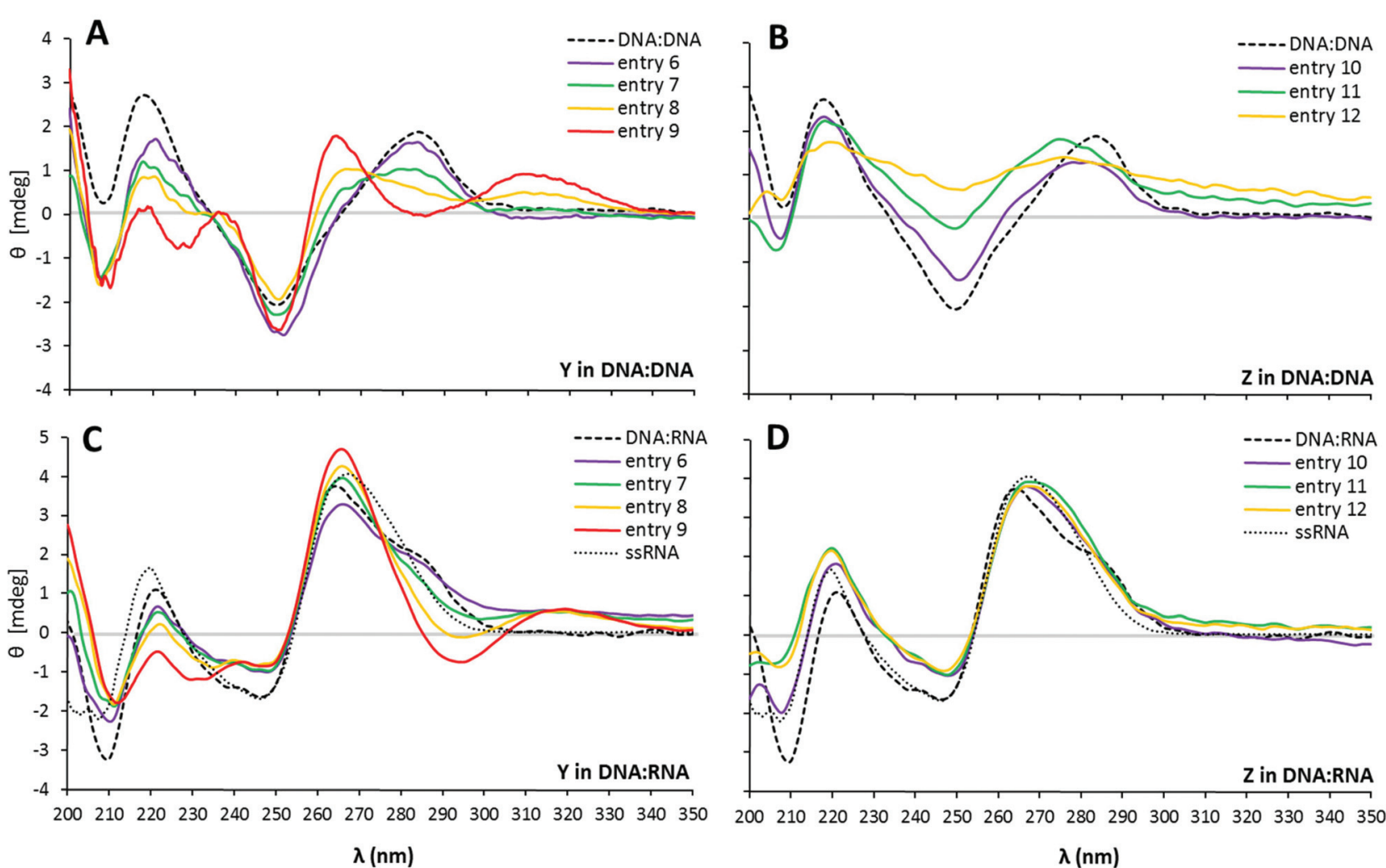

Fig. 4 CD spectra (200-350 nm) of (A) DNA : DNA duplexes featuring $Y$ at $10{ }^{\circ} \mathrm{C}$ (entries $6-9$ ), (B) DNA : DNA duplexes featuring $Z$ at $5{ }^{\circ} \mathrm{C}$ (entries 10-12), (C) DNA : RNA duplexes featuring $\mathrm{Y}$ at $10^{\circ} \mathrm{C}$ (entries 6-9), and (D) DNA: RNA duplexes featuring $\mathrm{Z}$ at $5{ }^{\circ} \mathrm{C}$ (entries $10-12$ ). Recorded in PBS buffer (2.5 mM Na $2 \mathrm{HPO}_{4}, 5.0 \mathrm{mM} \mathrm{NaH} \mathrm{PO}_{4}, 100 \mathrm{mM} \mathrm{NaCl}, 0.1 \mathrm{mM}$ EDTA, pH 7) using $5 \mathrm{~mm}$ quartz cuvettes and a split width of $2 \mathrm{~nm}$. 
band at $\sim 310 \mathrm{~nm}$ was completely absent in the case of $\mathbf{X}$. However, in general, the structural impacts by introducing $\mathbf{X}$ and $\mathbf{Y}$ in DNA:DNA duplexes are rather similar, and both induce a gradual shift towards an A-type duplex. ${ }^{6,7 a}$

The CD curve of the DNA : DNA duplex containing a single incorporation of $\mathbf{Z}$ (Fig. 4B, entry 10) was largely similar to the unmodified duplex-like in the case of $\mathbf{Y}$-suggesting that a single $\mathbf{Z}$ residue does not profoundly affect the secondary structure. With $2 \times \mathbf{Z}$ (entry 11), a small shift toward the more compact A-type duplex was observed, however, with $3 \times \mathbf{Z}$ (entry 12), the duplex structure appears essentially absent.

As shown in Fig. 4C and D, the unmodified DNA: RNA duplex adopts a conformation somewhere between the standard A- and B-type geometries with a sharp CD maximum at $\sim 265 \mathrm{~nm}$ (A-type), a shoulder at $285 \mathrm{~nm}$ (B-type), a positive band at $\sim 220 \mathrm{~nm}$ (B-type), and negative bands at $\sim 245 \mathrm{~nm}$ (B-type) and 210 (A-type). Upon a single incorporation of $\mathbf{Y}$ (Fig. 4C, entry 6) in the DNA : RNA duplex, no distinct change in the CD profile was observed, analogous to DNA: DNA. But with each additional incorporation of $\mathbf{Y}$ residues (entries 7-9), a gradual shift toward an A-type duplex was observed, portrayed by the drop in the intensities of the archetypal B-type bands at $\sim 285$ and $\sim 220 \mathrm{~nm}$, and an intensity gain at $\sim 265 \mathrm{~nm}$. This shift towards an A-type duplex and the new band at $240 \mathrm{~nm}$ was also observed in the CD spectra of duplexes featuring $\mathbf{X}$, although to a lesser degree. ${ }^{6,7}$ Like in the case of DNA:DNA, a weak band appears in the low-energy region $(\sim 320 \mathrm{~nm})$ of the duplexes containing $3 \times \mathbf{Y}$ and $4 \times \mathbf{Y}$, which was completely absent for the duplexes containing $\mathbf{X}$.
For the DNA : RNA duplexes containing Z (Fig. 4D), all CD spectra show that, in fact, no duplexes are formed upon mixing the complementary strands, which is particularly evident by the lack of any negative-to-positive Cotton effects in the 200-210 nm-region. The CD curves appear as duplicates of the recorded spectrum of the single-stranded RNA, except that they are slightly perturbed by the weak CD bands of the singlestranded DNA.

\section{Molecular modelling}

To better understand the thermal and structural changes induced by $\mathbf{X}, \mathbf{Y}$ and $\mathbf{Z}$ in duplexes, the monomers were subjected to molecular mechanical conformational analyses. Within their base moiety, the monomers contain two rotational axes, i.e. the bond between the triazole and the nucleobase $(\varphi)$, and the bond between the triazole and the phenyl/uracil substituents $(\psi)$. To facilitate speedy calculation, the sugar portions were replaced by a methyl group. These model structures were energy-minimized by DFT calculations under vacuum using the B3LYP hybrid functional and the 6-31G** basis set, and then subjected to coordinate scans using OPLS-2005 force field parameters ${ }^{21}$ (MacroModel V10.4, release $2014-2$ ) in GB/SA solvation. ${ }^{22}$ Scanning from $0-360^{\circ}$ in $1^{\circ}$ increments for both $\varphi$ and $\psi$ dihedral angles generated $361^{2}$ = 130321 structures per search, which were individually minimized, allowing all degrees of freedom to vary except $\varphi$ and $\psi$. The energy plots of the model compounds in their $(\varphi, \psi)$ spaces, and the global minimum structures in ball-and-stick models, are shown in Fig. 5.
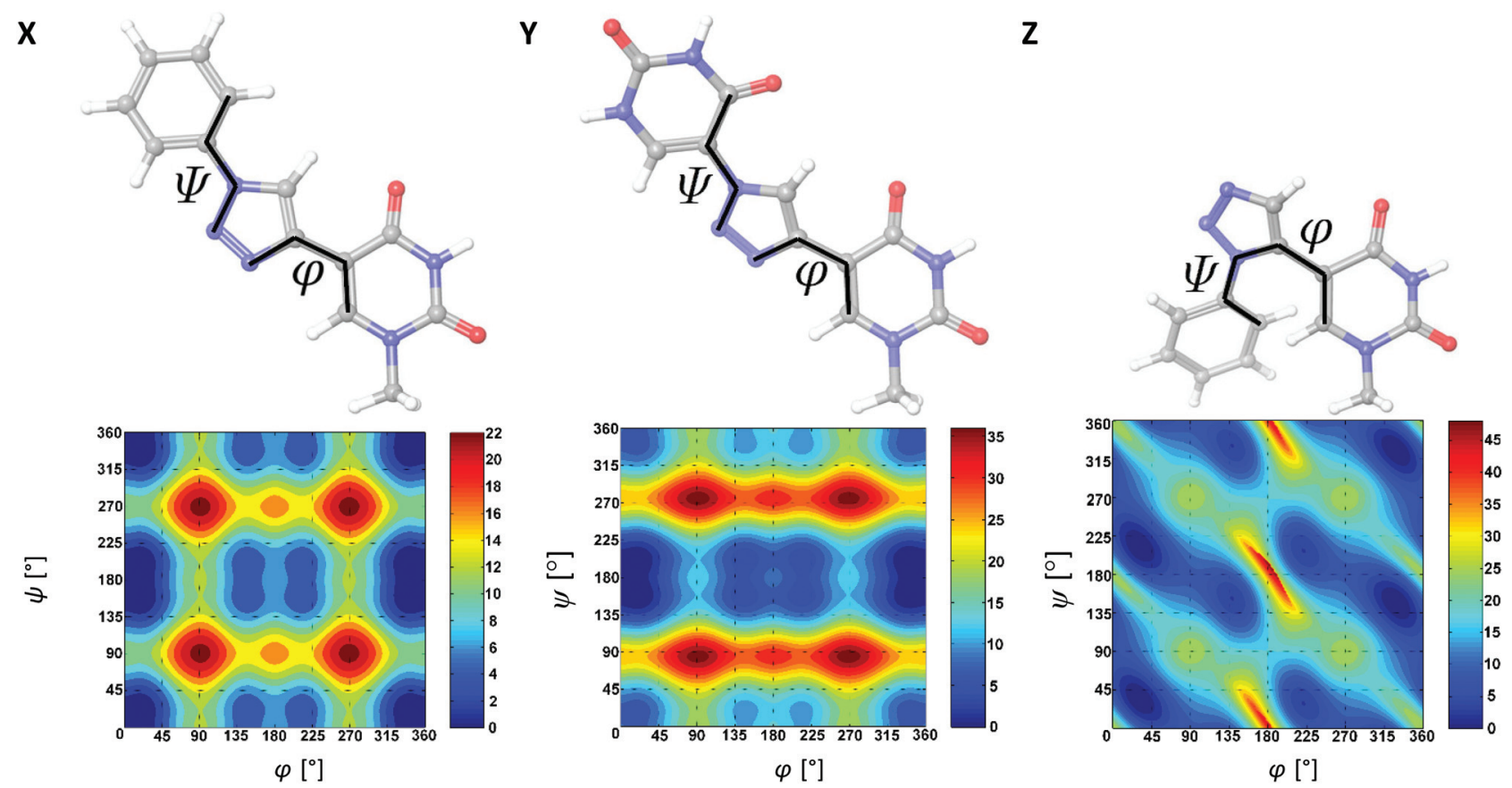

Fig. 5 Lowest-energy ball-and-stick models, and relative potential energy contour plots (in units of $\mathrm{kJ} \mathrm{mol}^{-1}$ ) of the model compounds of $\mathrm{X}, \mathrm{Y}$ and $\mathrm{Z}$ in their $(\varphi, \psi)$ spaces. The contour interval is set to $2 \mathrm{~kJ} \mathrm{~mol}^{-1}$ (is best viewed on screen). Calculations were carried out using OPLS-2005 parameters and using $1^{\circ}$ increments from $0-360^{\circ}$ for both $\varphi$ and $\psi$. 
As shown in the $(\varphi, \psi)$ contour maps, the conformational spaces for the model compounds of $\mathbf{X}$ and $\mathbf{Y}$ are somewhat similar and both contain a deep global minimum at $(\varphi, \psi r)=$ $\left(0^{\circ}, 180^{\circ}\right)$. The $\varphi=0^{\circ}$ minimum signifies a strong conformational preference for a syn coplanar nucleobase-triazole torsion stabilized by a weak $2.5 \AA \mathrm{CH}^{\cdots} \mathrm{O} \mathrm{O}$ interaction between the nucleobase $\mathrm{O} 4$ and the triazole $\mathrm{H}$ atom. The $\psi=180^{\circ}$ minimum in $\mathbf{Y}$ corresponds to an anti coplanar orientation, seemingly stabilized by another weak $2.4 \AA$ interaction between the distal uracil $\mathrm{O} 4$ atom and the triazole $\mathrm{H}$ atom. Therefore, both $\mathbf{X}$ and $\mathbf{Y}$ favor having the three ring systems in the same plane. Notably, the calculated barrier to conformational transition from the global minimum to various local minima is higher for $\mathbf{Y}$ than $\mathbf{X}$, which is, at least in parts, due to this interaction.

In contrast to $\mathbf{X}$ and $\mathbf{Y}$, the model compound of monomer $\mathbf{Z}$ favors a syn but non-coplanar orientation of the nucleosidetriazole bond. It has a pair of symmetry related global minima at $(\varphi, \psi)=\left(32^{\circ}, 34^{\circ} \pm 180^{\circ}\right)$ and $(\varphi, \psi)=\left(328^{\circ}, 146^{\circ} \pm 180^{\circ}\right)$. Both the two possible conformations with the three ring systems in the same plane are disfavored by steric hindrance, indicating that conjugation of $\pi$ electrons is effectively broken between the aromatic moieties. Interestingly, monomer $\mathbf{Z}$ has a pair of symmetry related secondary minima $\left(+2 \mathrm{~kJ} \mathrm{~mol}^{-1}\right)$ at $(\varphi, \psi)=\left(140^{\circ}, 154^{\circ} \pm\right.$ $\left.180^{\circ}\right)$ and $(\varphi, \psi)=\left(220^{\circ}, 206^{\circ} \pm 180^{\circ}\right)$, which are entirely enclosed within the $+8 \mathrm{~kJ} \mathrm{~mol}^{-1}$ contour of the global minimum.

In order to visualize how the 5-substituents of $\mathbf{X}, \mathbf{Y}$ and $\mathbf{Z}$ influence the helical topology of the duplexes, and to establish the degree of stacking of the aromatic moieties in the duplex, the global minimum structures of the duplexes containing $\mathbf{X}$, $\mathbf{Y}$ and $\mathbf{Z}$ were obtained from 5 ns molecular dynamics (MD) simulations using the all-atom AMBER* force field (MacroModel V10.4, release 2014-2) in GB/SA solvation. The unmodified duplexes and the duplexes featuring $\mathbf{X}$ and $\mathbf{Y}$ were modeled at a constant $25{ }^{\circ} \mathrm{C}$, whereas duplexes featuring $\mathbf{Z}$ were modeled at $5{ }^{\circ} \mathrm{C}$ in order for the geometry minimizations to successfully converge. The global minimum structures from the MD simulations are shown in Fig. 6 and 7 for modeled DNA : DNA and DNA : RNA structures, respectively.

As expected, the modeled DNA: DNA duplexes are B-type helices with the 5-substituents of $\mathbf{X}, \mathbf{Y}$ and $\mathbf{Z}$ situated in the major groove. In line with the CD spectra, no significant perturbation of the helix structure occurs when introducing single incorporations of $\mathbf{X}, \mathbf{Y}$ or $\mathbf{Z}$. As expected from the conformational analysis, the Watson-Crick face of the additional uracil moiety in $\mathbf{Y}$ is placed toward the core of the duplex. However, while the aromatic rings of $\mathbf{X}$ and $\mathbf{Y}$ are aligned in the plane of the nucleobases (perpendicular to the axis of the duplex), the phenyl group of monomer $\mathbf{Z}$ points away from the duplex core. This conformation of $\mathbf{Z}$ corresponds precisely to the energetically favored syn periplanar torsion of the nucleobase-triazole bond. In the duplex with $2 \times \mathbf{Z}$, the 5 -substituents are not aligned in parallel planes and do not appear to engage in any stacking interactions. In fact, one of the $\mathbf{Z}$ residues adopts the less-favored anti periplanar spatial orientation in

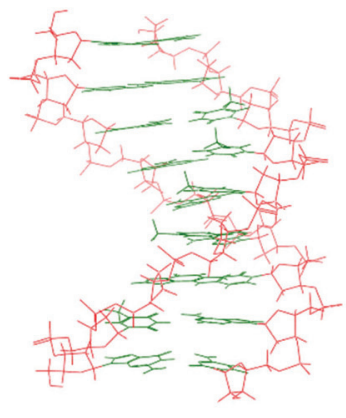

DNA:DNA

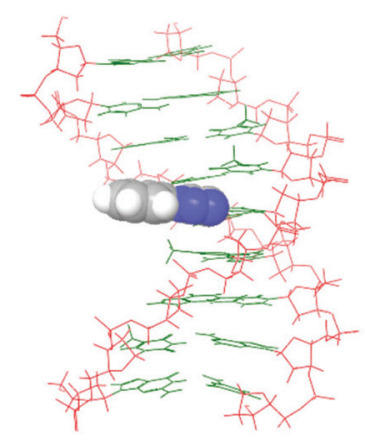

$1 \times \mathbf{X}$

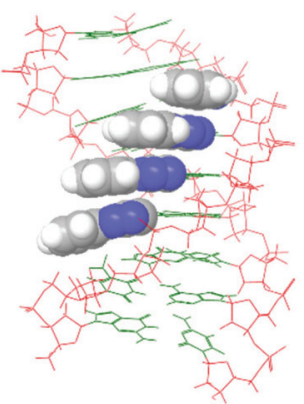

$4 \times X$

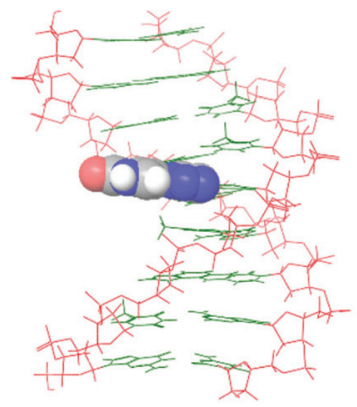

$1 \times Y$

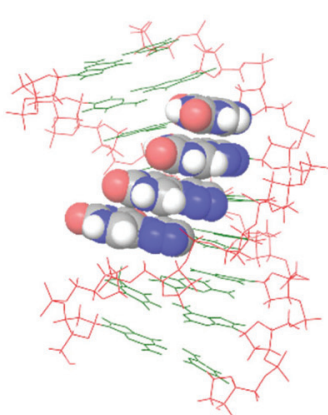

$4 \times Y$

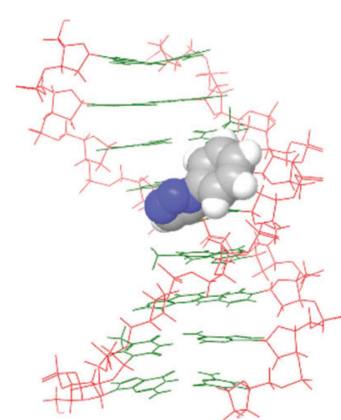

$1 \times \mathbf{Z}$

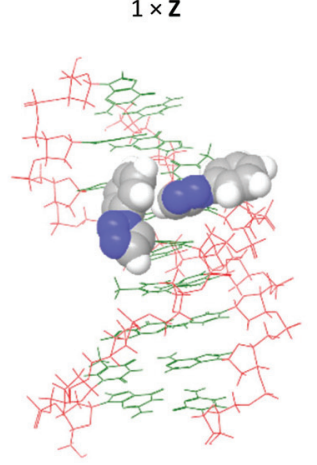

$2 \times Z$

Fig. 6 Global minimum structures obtained by 5 ns MD simulations of selected DNA: DNA duplexes from Table 1: monomer $X$ (entries 2 + 5), monomer $Y$ (entries $6+9$ ), and monomer $Z$ (entries $10+11$ ). The calculations were performed using the all-atom AMBER* force field in GB/SA solvation (van der Waals $8 \AA$ and electrostatics $20 \AA$ ). The 5 -substituents are shown with space-filling. 


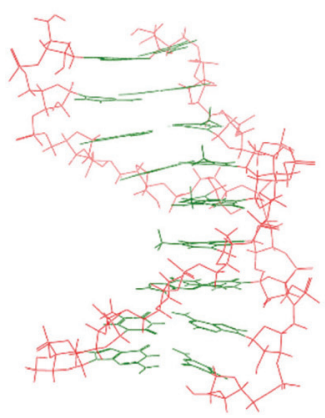

DNA:RNA

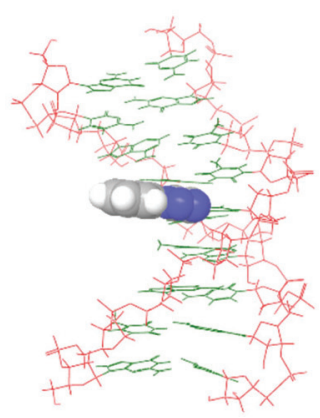

$1 \times x$

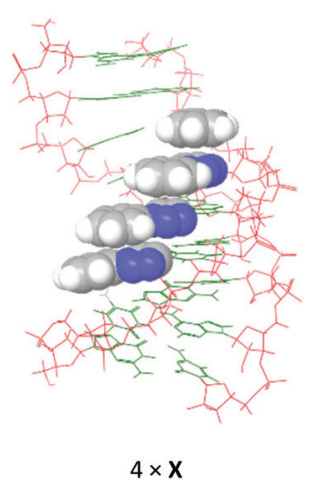

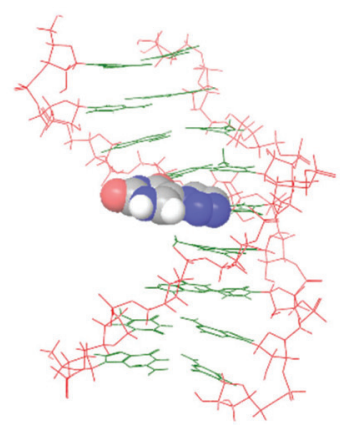

$1 \times Y$

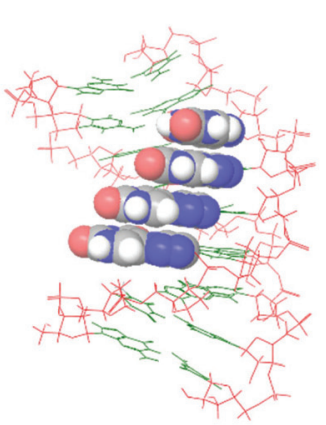

$4 \times Y$

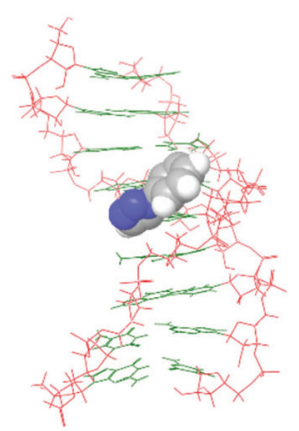

$1 \times z$

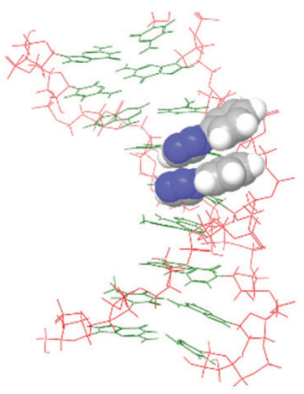

$2 \times Z$

Fig. 7 Global minimum structures obtained by 5 ns MD simulations of selected DNA: RNA duplexes from Table 1: monomer $X$ (entries $2+5$ ), monomer $Y$ (entries $6+9$ ), and monomer $Z$ (entries $10+11$ ). The calculations were performed using the all-atom AMBER* force field in GB/SA solvation (van der Waals $8 \AA$ and electrostatics $20 \AA$ ). . The 5 -substituents are shown with space-filling.

order to accommodate both modifications. This behavior appears to induce a slight unwinding of the helix. In the duplexes with $4 \times \mathbf{X}$ or $4 \times \mathbf{Y}$, the 5 -substituents appear to strongly stack in the major groove, although they appear to shift the helix toward the more compact A/B-type. This is particularly apparent in the duplex with $4 \times \mathbf{Y}$, where the bending of the duplex appears to enable a few additional 1.8-2.0 hydrogen bonding interactions between the additional uracil and the nucleobases, while at the same time conserving all Watson-Crick base pairs.

Essentially the same picture was observed for $\mathbf{X}, \mathbf{Y}$ and $\mathbf{Z}$ in DNA : RNA structures. Monomers $\mathbf{X}$ and $\mathbf{Y}$ are well-accommodated in the major grooves of the duplexes, and consecutive incorporations stack strongly and induce a slight compression of the duplex. But while the $\mathbf{Z}$ residue almost retains the same conformation as in the case of DNA: DNA, even a single incorporation appears to induce a slight unwinding of the helix. Notably, the two adjacent incorporations of $\mathbf{Z}$ stack efficiently on the outside of the duplex, however, in doing so, they induce unwinding of the duplex.

\section{Discussion}

Although some excellent artificial DNA building blocks, ${ }^{23}$ such as locked nucleic acids, ${ }^{24}$ have pushed the stability of nucleic acid duplexes to a new level, the strategy of using simple 5-sub- stituted pyrimidine nucleotides benefits from their easy technical preparation and their less perturbing consequences on the sugar pucker and helix geometry, which is important for many biological applications. With our previously-published monomer $\mathbf{X},{ }^{6,7 a}$ we have devised a feasible technique to significantly stabilize duplexes by enhancing the inherent stacking interactions of the DNA: RNA duplexes, and recently we have shown that 5-substituted phenylpyrazole dC analogs stack particularly strongly with $\mathbf{X},{ }^{17}$ allowing efficient targeting of homo-purine sequences.

In the present study, we have evaluated the consequences of replacing the apolar phenyl substituent of $\mathbf{X}$ with the very polar uracil substituent (monomer $\mathbf{Y}$ ), and the consequences of swapping the 1,4-disubstituted triazole in $\mathbf{X}$ with a 1,5-disubstituted derivative (monomer $\mathbf{Z}$ ). The thermal and structural effects imposed by these two new analogs of $\mathbf{X}$ in the center of 9-mer DNA: DNA and DNA: RNA duplexes were examined by UV and CD spectroscopy. Monomers $\mathbf{Y}$ and $\mathbf{Z}$ were conveniently synthesized in a few synthetic steps starting from 5-ethynyl-2'-deoxyuridine by employing high-yielding $\mathrm{Cu}(\mathrm{I})^{-}$and $\mathrm{Ru}(\mathrm{II})$-catalyzed alkyne-azide cycloadditions, respectively, and their incorporation into oligonucleotides as DMT-protected phosphoramidites $\mathbf{3}$ and 8 was very efficient.

Compared to $\mathbf{X}$, the oligonucleotide featuring a single polar $\mathbf{Y}$ residue was found to have a slightly higher affinity toward complementary RNA and a significantly higher affinity toward 
complementary DNA, which appears to arise from the fact that the uracil substituent on $\mathbf{Y}$ is much better solvated in the duplex than the hydrophobic phenyl group on $\mathbf{X}$. With multiple modifications, monomer $\mathbf{Y}$ appears to be equipotent to $\mathbf{X}$ in terms of increasing the affinity toward complementary RNA. That is, for each triazole moiety stacking on top of another triazole moiety, an increase in the $T_{\mathrm{m}}$ of the duplex of about $+7{ }^{\circ} \mathrm{C}$ was observed. In general, fine base-pairing fidelity was observed with the oligonucleotide containing four $\mathbf{Y}$ residues, although a central A to $\mathrm{C}$ mismatch discrimination was smaller compared to the case of $\mathbf{X}$. According to $\mathrm{CD}$ spectroscopy and molecular modelling, some differences in the duplex structure were indicated. Notably, $4 \times \mathbf{Y}$ residues induce a slight bending of the duplex, possibly due to more efficient stacking interactions and hydrogen bonding interactions across the major groove, and the $\mathrm{CD}$ spectrum supported this deviation from the standard A/B-type duplex. Indeed, these secondary interactions via the additional uracil moiety makes monomer $\mathbf{Y}$ a so-called double-headed nucleotide..$^{25,26}$ We have previously decorated DNA duplexes with additional nucleobases in the major groove ${ }^{26}$ for use as double-coding DNA systems that could turn out to be important tools in nucleic acid nanotechnology in the future. With monomer $\mathbf{Y}$, with its triazole linker between the nucleobases, we now have a double-headed nucleotide with unprecedented thermostabilizing properties.

In the case of targeting DNA, oligonucleotides containing at least three consecutive $\mathbf{Y}$ were found to display increased affinities toward complementary DNA relative to the unmodified oligonucleotide; and, in doing so, they significantly outperform $\mathbf{X}$. This stacking affinity inequivalence between $\mathbf{X}$ and $\mathbf{Y}$ in DNA: DNA but not in DNA : RNA indicates that the higher vertical rise of B-type helices houses the stacking of polar aromatic moieties better than apolar moieties. Nevertheless, it is interesting to note that Kool and co-workers found that halogenated nucleoside isosteres stack more efficiently than the canonical nucleobases when positioned as dangling residues, ${ }^{14 c, 27}$ and therefore they concluded that nonpolar analogues stack more strongly, in general, than the more polar natural bases. ${ }^{14 \mathrm{c}}$ We now conclude that this correlation appears to be reversed, when the modification is situated in the major groove. Upon each incorporation of $\mathbf{Y}$ in DNA: DNA, a gradual shift toward an A/B-type helix geometry was observed, however, this geometry impact is similar to $\mathbf{X}$ and is presumably negligible in longer sequences.

Surprisingly, oligonucleotides bearing monomer $\mathbf{Z}$ were found to have extraordinarily low affinities toward both complementary DNA and RNA compared to the unmodified oligonucleotide. This result is most precisely explained in terms of structural issues, since the helical geometries of the resulting duplexes were severely affected by the presence of $\mathbf{Z}$ according to the molecular modeling. Either way, this is indicative of the extraordinary destabilizing effects of $\mathbf{Z}$ in duplexes. Remarkably, this complete depression in duplex formation arises from just a delicate positional isomerism of the triazole ring $(1,4$ vs. 1,5$)$.

\section{Conclusions}

In this study, the efficiency of stacking interactions in the major groove of our previously published 1-phenyltriazol-4-yl scaffold (monomer $\mathbf{X}$ ) have been altered by, respectively, replacing the phenyl substituent with a polar uracil-5-yl substituent (monomer $\mathbf{Y}$ ), and replacing the 1,4-triazole with its 1,5-derivative (monomer $\mathbf{Z}$ ). While consecutive incorporations of monomer $\mathbf{X}$ thermally stabilizes DNA : RNA duplexes significantly due to efficient stacking, the corresponding 1-phenyltriazol-5-yl modification (monomer $\mathbf{Z}$ ) does not engage in stacking interactions and effectively undermines duplex formation. Thus, this study signifies that the precise spatial orientation of the phenyltriazole moieties is absolutely crucial for optimal duplex stability. Concerning the polarity of the 5-substituent, the single incorporation of a polar 1-uracil-5-yltriazol4-yl modification (monomer $\mathbf{Y}$ ) was found to be energetically much more favored than the apolar 5-substituent of monomer $\mathbf{X}$. Comparing the thermal effects of multiple incorporations, the stacking of $\mathbf{Y}$ residues appears, in general, marginally better than the stacking of $\mathbf{X}$ residues in terms of increasing the melting temperatures of the DNA: RNA duplexes, and $\mathbf{Y}$ is clearly superior to $\mathbf{X}$ in terms of stabilizing homo-DNA duplexes. As a result, monomer $\mathbf{Y}$ is a promising candidate in RNA- and DNA-targeting oligonucleotides.

\section{Experimental section}

All reagents were used as supplied except $\mathrm{CH}_{2} \mathrm{Cl}_{2}$, which was distilled prior to use. Microwave irradiated reactions were conducted in sealed reaction vessels in a Biotage Initiator ${ }^{+}$instrument using external surface sensor probes. All reactions were monitored by TLC using silica gel $\left(60 \mathrm{~F}_{254}\right)$ precoated plates. Flash chromatography was performed using silica gel 60 (particle size $0.040-0.063 \mathrm{~mm}$ ). For the purification of DMT-protected nucleosides, the silica gel was pretreated with $1 \%$ pyridine in $\mathrm{CH}_{2} \mathrm{Cl}_{2}(\mathrm{v} / \mathrm{v})$. HRMS-ESI was recorded on a quadrupole-time of flight instrument in positive ion mode with an accuracy of $\pm 5 \mathrm{ppm} .{ }^{1} \mathrm{H},{ }^{13} \mathrm{C}$ and ${ }^{31} \mathrm{P}$ NMR spectra were recorded at $400.12 \mathrm{MHz}, 100.62 \mathrm{MHz}$ and $161.97 \mathrm{MHz}$, respectively. Chemical shifts are reported in ppm relative to tetramethylsilane $\left(\delta_{\mathrm{H}, \mathrm{C}} 0 \mathrm{ppm}\right)$ or the deuterated solvents (DMSO $\left.\delta_{\mathrm{c}} 39.5 \mathrm{ppm}, \mathrm{CDCl}_{3} \delta_{\mathrm{c}} 77.16 \mathrm{ppm}\right)$. For ${ }^{31} \mathrm{P}$ NMR spectra, $85 \%$ $\mathrm{H}_{3} \mathrm{PO}_{4}$ was used as external standard. 2D spectra (HSQC, COSY and $\mathrm{HMBC}$ ) have been used in assigning ${ }^{1} \mathrm{H}$ and ${ }^{13} \mathrm{C}$ NMR signals.

\section{5-Azidouracil ${ }^{16}$}

To a magnetically stirred solution of 5-aminouracil $(2.25 \mathrm{~g}$; $17.7 \mathrm{mmol})$ in $\mathrm{H}_{2} \mathrm{O}(150 \mathrm{~mL})$ was added $\mathrm{TsOH} \cdot \mathrm{H}_{2} \mathrm{O}(30.3 \mathrm{~g}$; $160 \mathrm{mmol}$ ) and $\mathrm{NaNO}_{2}$ (11.0 g; $\left.160 \mathrm{mmol}\right)$. The reaction mixture was stirred at rt for $1 \mathrm{~h}$, upon which $\mathrm{NaN}_{3}(1.84 \mathrm{~g}$; $28.4 \mathrm{mmol}$ ) was slowly added. After the bubbles had settled ( $15 \mathrm{~min}$ ), the reaction mixture was cooled to $5{ }^{\circ} \mathrm{C}$, and the precipitate was filtered through a sintered glass funnel to 
obtain 5-azidouracil as a light beige solid (1.28 g; $8.4 \mathrm{mmol}$ ). Yield: $47 \%$. $R_{\mathrm{f}} 0.4$ (50\% $\mathrm{MeOH}$ in $\left.\mathrm{CH}_{2} \mathrm{Cl}_{2}\right)$. M.p. $98-99{ }^{\circ} \mathrm{C}$ (decomp.) ${ }^{1} \mathrm{H}$ NMR (400 MHz, DMSO-d 6 ): $\delta 11.55$ (br, $1 \mathrm{H}, \mathrm{NH}$ ), 10.97 (br, 1H, NH), 7.31 (s, 1H; H6). ${ }^{13} \mathrm{C}$ NMR (101 MHz, DMSO-d ${ }_{6}$ ): $\delta 160.7$ (C4), 150.0 (C2), 130.0 (C6), 112.0 (C5). HRMS-ESI ${ }^{+}$: calcd for $\left[\mathrm{C}_{4} \mathrm{H}_{3} \mathrm{~N}_{5} \mathrm{O}_{2}\right]_{2}-\mathrm{Na}^{+} \mathrm{m} / z$ 329.0466, found $m / z 329.0433$.

5'-O-(4,4'-Dimethoxytrityl)-5-(1-uracil-5-yl-1H-1,2,3-triazol4-yl)-2'-deoxyuridine (2). To a magnetically stirred solution of nucleoside 1 (300 mg; $0.54 \mathrm{mmol}$ ) and 5-azidouracil (165 mg; $1.08 \mathrm{mmol}$ ) in a mixture of $\mathrm{H}_{2} \mathrm{O}$ and $t$-BuOH $(20 \mathrm{~mL} ; 1: 1)$, sodium ascorbate $(107 \mathrm{mg} ; 0.54 \mathrm{mmol})$ and $\mathrm{CuSO}_{4} \cdot 5 \mathrm{H}_{2} \mathrm{O}$ (40 mg; $162 \mu \mathrm{mol}$ ) were added, and the reaction mixture was stirred at $\mathrm{rt}$ for $3 \mathrm{~h}$. The reaction mixture was diluted with EtOAc $(100 \mathrm{~mL})$ and washed with brine $(50 \mathrm{~mL})$. The mixture was filtered through a short Celite pad, and the organic phase was separated and concentrated under reduced pressure. The residue was purified by flash chromatography $(0-10 \% \mathrm{MeOH}$ in $\mathrm{CH}_{2} \mathrm{Cl}_{2}$ ) to obtain nucleoside 2 as a white solid (288 mg; $0.41 \mathrm{mmol})$. Yield: $75 \% . R_{\mathrm{f}} 0.5\left(10 \% \mathrm{MeOH}\right.$ in $\left.\mathrm{CH}_{2} \mathrm{Cl}_{2}\right)$. ${ }^{1} \mathrm{H}$ NMR (400 MHz, DMSO-d 6 ): $\delta 11.79$ (br, 2H, NH), 11.55 (br, $1 \mathrm{H}, \mathrm{NH}), 8.51$ (s, 1H, triazole $\mathrm{H} 5), 8.38(\mathrm{~s}, 1 \mathrm{H}, \mathrm{H} 6), 8.06(\mathrm{~s}, 1 \mathrm{H}$, H6 in external uracil), 7.39 (d, $J=7.4 \mathrm{~Hz}, 2 \mathrm{H}, \mathrm{DMT}), 7.32-7.23$ (m, 6H, DMT), $7.18(\mathrm{t}, J=7.3 \mathrm{~Hz}, 1 \mathrm{H}, \mathrm{DMT}), 6.88-6.82(\mathrm{~m}, 4 \mathrm{H}$, DMT), $6.19\left(\mathrm{t}, J=6.5 \mathrm{~Hz}, 1 \mathrm{H}, \mathrm{H} 1^{\prime}\right), 5.36\left(\mathrm{br}, 1 \mathrm{H}, 3^{\prime}-\mathrm{OH}\right)$, 4.24-4.19 (m, 1H, H3'), 3.96 (q, $\left.J=4.3 \mathrm{~Hz}, 1 \mathrm{H}, \mathrm{H} 4^{\prime}\right), 3.71$ (s, 3H, DMT), 3.70 (s, 3H, DMT), 3.34 (br, 1H, 3'-OH), 3.23 (d, $J=$ $\left.4.3 \mathrm{~Hz}, 2 \mathrm{H}, \mathrm{H} 5{ }^{\prime}, \mathrm{H} 5^{\prime \prime}\right), 2.30-2.25$ (m, 2H, H2', H2 $\left.{ }^{\prime \prime}\right) .{ }^{13} \mathrm{C} \mathrm{NMR}$ (101 MHz, DMSO-d 6 ): $\delta 161.0$ (C4), 159.3 (C4 in external uracil), 157.9 (DMT), 150.2 (C2), 149.4 (C2 in external uracil), 144.7 (DMT), 138.53 (triazole C4), 138.52 (C6 in external uracil), 135.7 (C6), 135.4, 129.6, 127.7, 127.6, 126.5 (DMT), 123.6 (triazole C5), 113.1 (DMT), 112.3 (C5), 104.8 (C5 in external uracil), 85.7 (C4'), 85.6 (DMT), 85.2 (C1'), 70.3 (C3'), 63.6 (C5'), 54.9 (DMT), 48.5 (C2'). HRMS-ESI ${ }^{+}$: calcd for $\mathrm{C}_{36} \mathrm{H}_{33} \mathrm{~N}_{7} \mathrm{O}_{9}-\mathrm{Na}^{+} m / z$ 730.2232, found $m / z 730.2218$.

5'-O-(4,4'-Dimethoxytrityl)-5-(1-uracil-5-yl-1H-1,2,3-triazol4-yl)-3'-O-(P-(2-cyanoethoxy)-,$N$-diisopropylaminophos-phinyl)2'-deoxyuridine (3). Nucleoside 2 (280 mg; $0.40 \mathrm{mmol}$ ) was coevaporated with anhydrous 1,2-DCE (10 mL), and dissolved in anhydrous $\mathrm{CH}_{2} \mathrm{Cl}_{2}(3 \mathrm{~mL})$, upon which diisopropylammonium tetrazolide (135 mg; $0.79 \mathrm{mmol}$ ) and 2-cyanoethyl- $N, N, N^{\prime}, N^{\prime}$ tetraisopropyl-phosphordiamidite (238 mg; $0.79 \mathrm{mmol}$ ) were added to the magnetically stirred solution. The reaction mixture was stirred at rt for $12 \mathrm{~h}$, and concentrated under reduced pressure. The residue was purified by flash chromatography (0-5\% $\mathrm{MeOH}$ in $\mathrm{CH}_{2} \mathrm{Cl}_{2}$ ) to afford a colorless oil, which was dissolved in $\mathrm{CH}_{2} \mathrm{Cl}_{2}(1 \mathrm{~mL})$ and poured onto cold hexanes $(100 \mathrm{~mL})$. The resulting precipitate was collected by decantation to obtain nucleoside phosphoramidite 3 as a white solid (254 mg, $0.28 \mathrm{mmol})$. Yield: $71 \%$. $R_{\mathrm{f}} 0.5$ (5\% $\mathrm{MeOH}$ in $\left.\mathrm{CH}_{2} \mathrm{Cl}_{2}\right) .{ }^{31} \mathrm{P}$ NMR (162 $\left.\mathrm{MHz}, \mathrm{CDCl}_{3}\right): \delta$ 148.77, 148.54. HRMS-ESI ${ }^{+}$: calcd for $\mathrm{C}_{45} \mathrm{H}_{50} \mathrm{~N}_{9} \mathrm{O}_{10} \mathrm{P}-\mathrm{Na}^{+} \mathrm{m} / z$ 930.3310, found $\mathrm{m} / z 930.3342$.

3',5'-Di-O-acetyl-5-(1-phenyl-1H-1,2,3-triazol-5-yl)-2'-deoxyuridine (5). To a stirred solution of nucleoside 4 (249 mg;
$0.74 \mathrm{mmol})$ in anhydrous THF $(4 \mathrm{~mL})$, were added $\mathrm{Cp}^{*} \mathrm{RuCl}-$ $\left(\mathrm{PPh}_{3}\right)_{2}$ (59 mg; $\left.81 \mu \mathrm{mol}\right)$, phenylazide $(\sim 0.5 \mathrm{M}$ solution in MTBE; $1.48 \mathrm{~mL} ; 0.74 \mathrm{mmol})$. The reaction mixture was subjected to microwave irradiation at $100{ }^{\circ} \mathrm{C}$ for $1 \mathrm{~h}$. The mixture was concentrated under reduced pressure and purified by flash chromatography $\left(0-5 \% \mathrm{MeOH}\right.$ in $\left.\mathrm{CH}_{2} \mathrm{Cl}_{2}\right)$ to obtain nucleoside 5 as a light reddish solid (269 $\mathrm{mg} ; 0.59 \mathrm{mmol}$ ). Yield: $80 \%$. $R_{\mathrm{f}} 0.4$ (5\% MeOH in $\left.\mathrm{CH}_{2} \mathrm{Cl}_{2}\right) .{ }^{1} \mathrm{H} \mathrm{NMR}(400 \mathrm{MHz}$, DMSO-d $\left.{ }_{6}\right): \delta 11.72(\mathrm{br}, 1 \mathrm{H}, \mathrm{NH}), 7.96(\mathrm{~s}, 1 \mathrm{H}$, triazole $\mathrm{H} 5), 7.87$ (s, 1H, H6), 7.60-7.49 (m, 5H, phenyl H), $6.15(\mathrm{t}, J=7.0,1 \mathrm{H}$, H1'), 5.13-5.11 (m, 1H, H3'), 4.19-4.12 (m, 3H, H4', H5', H5'), 2.51-2.49 (m, 1H, H2'), 2.38 (ddd, $J=14.4,7.0,2.8 \mathrm{~Hz}, 1 \mathrm{H}$, H2"), 2.06 (s, 3H, acetyl O), 1.96 (s, 3H, acetyl O). ${ }^{13} \mathrm{C}$ NMR (101 MHz, DMSO-d ${ }_{6}$ ): $\delta 170.0$ (acetyl CO), 169.9 (acetyl CO), 160.3 (C4), 149.6 (C2), 141.3 (triazole C5), 136.6 (triazole C4), 134.8 (C6), 129.4 (phenyl C3), 129.1 (phenyl C4), 128.7 (phenyl C1), 124.1 (phenyl C2), 101.6 (C5), 84.9 (C1'), 81.3 (C4'), 73.6 (C3'), 63.4 (C5'), 35.9 (C2'), 20.7 (acetyl $\mathrm{CH}_{3}$ ), 20.4 (acetyl $\mathrm{CH}_{3}$ ). HRMS-ESI ${ }^{+}$: calcd for $\mathrm{C}_{21} \mathrm{H}_{21} \mathrm{~N}_{5} \mathrm{O}_{7}-\mathrm{Na}^{+} \mathrm{m} / z$ 478.1333, found $\mathrm{m} / z$ 478.1351 .

5-(1-Phenyl-1H-1,2,3-triazol-5-yl)-2'-deoxyuridine (6). Nucleoside 5 (264 $\mathrm{mg} ; 0.58 \mathrm{mmol}$ ) was dissolved in anhydrous $\mathrm{MeOH}$ (4 mL) and methanolic ammonia (7 N, $4 \mathrm{~mL} ; 28.4 \mathrm{mmol}$ ) was added. The reaction mixture was magnetically stirred at $\mathrm{rt}$ for $48 \mathrm{~h}$, and concentrated under reduced pressure. The residue was purified by flash chromatography $(0-15 \% \mathrm{MeOH}$ in $\mathrm{CH}_{2} \mathrm{Cl}_{2}$ ) to obtain nucleoside 6 as a white foam $(183 \mathrm{mg}$; $0.49 \mathrm{mmol})$. Yield: $85 \%$. $R_{\mathrm{f}} 0.2\left(10 \% \mathrm{MeOH}\right.$ in $\left.\mathrm{CH}_{2} \mathrm{Cl}_{2}\right) \cdot{ }^{1} \mathrm{H}$ NMR (400 MHz, DMSO-d ${ }_{6}$ ): $\delta 11.63$ (br, 1H, NH), 8.07 (s, 1H, triazole $\mathrm{H} 5), 7.92(\mathrm{~s}, 1 \mathrm{H}, \mathrm{H} 6), 7.58-7.48(\mathrm{~m}, 5 \mathrm{H}$, phenyl $\mathrm{H})$, $6.12\left(\mathrm{t}, J=6.5 \mathrm{~Hz}, 1 \mathrm{H}, \mathrm{H} 1^{\prime}\right), 5.23$ (d, $\left.J=4.3 \mathrm{~Hz}, 1 \mathrm{H}, 3^{\prime}-\mathrm{OH}\right), 4.97$ (t, $\left.J=4.9 \mathrm{~Hz}, 1 \mathrm{H}, 5^{\prime}-\mathrm{OH}\right), 4.16-4.09\left(\mathrm{~m}, 1 \mathrm{H}, \mathrm{H} 3^{\prime}\right), 3.75(\mathrm{q}, J=$ $\left.3.4 \mathrm{~Hz}, 1 \mathrm{H}, \mathrm{H} 4^{\prime}\right), 3.51-3.41$ (m, 2H, H5', H5'), 2.11 (ddd, $J=$ 13.2, 6.5, $\left.3.7 \mathrm{~Hz}, 1 \mathrm{H}, \mathrm{H} 2^{\prime}\right), 1.99$ (dt, $\left.J=13.2,6.5,1 \mathrm{H}, \mathrm{H} 2{ }^{\prime \prime}\right) .{ }^{13} \mathrm{C}$ NMR (101 MHz, DMSO-d ${ }_{6}$ ): $\delta 160.4$ (C4), 149.7 (C2), 141.5 (C6), 136.7 (triazole C4), 134.6 (triazole C5), 130.5 (phenyl C1), 129.4 (phenyl C3), 129.1 (phenyl C4), 124.3 (phenyl C2), 101.0 (C5), 87.5 (C4'), 84.6 (C1'), 69.9 (C3'), 60.8 (C5'), 40.1 (C2'). HRMS-ESI ${ }^{+}$: calcd for $\mathrm{C}_{17} \mathrm{H}_{17} \mathrm{~N}_{5} \mathrm{O}_{5}-\mathrm{Na}^{+} \mathrm{m} / z$ 394.1122, found $\mathrm{m} / \mathrm{z}$ 394.1123.

5'-O-(4,4'-Dimethoxytrityl)-5-(1-phenyl-1H-1,2,3-triazol-5-yl)2'-deoxyuridine (7). Nucleoside 6 (109 mg; $0.29 \mathrm{mmol}$ ) was coevaporated with anhydrous pyridine $(2 \times 5 \mathrm{~mL})$ and dissolved in anhydrous pyridine (10 mL). DMTCl (129 mg; $0.38 \mathrm{mmol}$ ) was added and the reaction mixture was magnetically stirred at rt for $18 \mathrm{~h}$. The mixture was concentrated under reduced pressure and purified by flash chromatography $(0-5 \% \mathrm{MeOH}$ in $\mathrm{CH}_{2} \mathrm{Cl}_{2}$ ) to obtain nucleoside 7 as a light yellow solid (112.6 mg; $0.17 \mathrm{mmol})$. Yield: 57\%. $R_{\mathrm{f}} 0.7(10 \% \mathrm{MeOH}$ in $\mathrm{CH}_{2} \mathrm{Cl}_{2}$ ). ${ }^{1} \mathrm{H}$ NMR (400 MHz, DMSO-d 6 ): $\delta 11.71$ (br, $1 \mathrm{H}, \mathrm{NH}$ ), $7.70(\mathrm{~s}, 1 \mathrm{H}$, triazole $\mathrm{H} 5), 7.63(\mathrm{~s}, 1 \mathrm{H}, \mathrm{H} 6), 7.44-7.40(\mathrm{~m}, 3 \mathrm{H}$, phenyl), 7.36-7.30 (m, 4H, phenyl, DMT), 7.24-7.12 (m, 7H, DMT), 6.83 (d, $J=7.5 \mathrm{~Hz}, 2 \mathrm{H}, \mathrm{DMT}), 6.82$ (d, $J=7.5 \mathrm{~Hz}, 4 \mathrm{H}$, DMT), $6.14\left(\mathrm{t}, J=6.4 \mathrm{~Hz}, 1 \mathrm{H}, \mathrm{H} 1^{\prime}\right), 5.30(\mathrm{~d}, J=4.7 \mathrm{~Hz}, 1 \mathrm{H}$, 3'-OH), 4.02-3.97 (m, 1H, H3'), 3.87-3.84 (m, 1H, H4'), 3.69 (s, 6H, DMT), 3.10-3.02 (m, 2H, H5', H5'), 2.22-2.08 (m, 2H, H2', 
H2"). ${ }^{13} \mathrm{C}$ NMR (101 MHz, DMSO-d ${ }_{6}$ ): $\delta 160.3$ (C4), 158.00 (DMT), 157.95 (C2), 144.5 (DMT), 140.5 (C6), 136.6 (triazole C4), 136.5 (triazole C5), 134.4, 129.9, 129.6, 129.4, 129.3, 129.0, 127.7, 127.5, 113.0 (phenyl, DMT), 101.3 (C5), 85.5 (C4'), 85.4 (C1'), 70.0 (C3'), 62.9 (C5'), 54.9 (DMT), 54.9 (DMT), 40.5 (C2'). HRMS-ESI ${ }^{+}$: calcd for $\mathrm{C}_{38} \mathrm{H}_{35} \mathrm{~N}_{5} \mathrm{O}_{7}-\mathrm{Na}^{+} \mathrm{m} / z$ 696.2429, found $\mathrm{m} / \mathrm{z}$ 696.2433.

5'-O-(4,4'-Dimethoxytrityl)-5-(1-phenyl-1H-1,2,3-triazol-5-yl)3'-O-(P-(2-cyanoethoxy)-N,N-diisopropylaminophosphin-yl)-2'deoxyuridine (8). Nucleoside 7 (71 mg; $105 \mu \mathrm{mol}$ ) was co-evaporated with anhydrous 1,2-DCE $(2 \times 2 \mathrm{~mL})$ and dissolved in anhydrous 1,2-DCE (4 mL). Diisopropylammonium tetrazolide (36 mg; $0.21 \mathrm{mmol}$ ) and 2-cyanoethyl- $N, N, N^{\prime}, N^{\prime}$-tetraisopropylphosphor-diamidite (63 mg; $0.21 \mathrm{mmol}$ ) were added, and the reaction mixture was magnetically stirred at $\mathrm{rt}$ for $18 \mathrm{~h}$. The mixture was concentrated under reduced pressure, and purified by flash chromatography $\left(0-5 \% \mathrm{MeOH}\right.$ in $\left.\mathrm{CH}_{2} \mathrm{Cl}_{2}\right)$ to afford a colorless oil, which was dissolved in $\mathrm{CH}_{2} \mathrm{Cl}_{2}(1 \mathrm{~mL})$ and poured onto cold hexanes $(100 \mathrm{~mL})$. The resulting precipitate was collected by filtration to obtain nucleoside phosphoramidite 8 as light brown foam (46 mg, $0.28 \mathrm{mmol}$ ). Yield: $50 \%$. $R_{\mathrm{f}} 0.5\left(5 \% \mathrm{MeOH}\right.$ in $\left.\mathrm{CH}_{2} \mathrm{Cl}_{2}\right) .{ }^{31} \mathrm{P} \mathrm{NMR}(162 \mathrm{MHz}$, $\left.\mathrm{CDCl}_{3}\right): \quad \delta$ 149.05, 148.86. HRMS-ESI ${ }^{+}$: calcd for $\mathrm{C}_{47} \mathrm{H}_{52} \mathrm{~N}_{7} \mathrm{O}_{8} \mathrm{P}_{-} \mathrm{Na}^{+} m / z$ 930.3310, found $m / z$ 930.3342.

\section{Synthesis of oligonucleotides}

Oligonucleotides were synthesized on a fully-automated DNA synthesizer in $\sim 0.2 \mu \mathrm{mol}$ scale loaded on $500 \AA$ controlled-pore glass (CPG) supports using the phosphoramidite approach and following the manufacturer's protocol. Double coupling $(2 \times 5 \mathrm{~min})$ cycles were used for commercial phosphoramidites and prolonged coupling times (20 minutes) were used for the modified phosphoramidites 3 and 8 . The phosphoramidites were activated using $1 \mathrm{H}$-tetrazole, and incorporated into oligonucleotides via manual couplings: $10 \mu \mathrm{mol}$ of the modified phosphoramidite was dissolved in anhydrous MeCN (2 mL) and treated with $1 H$-tetrazole $(3 \mathrm{~mL}, 0.45 \mathrm{M}$ solution in $\mathrm{MeCN}$ ), and infused into the reaction compartment. The stepwise coupling efficiencies were monitored by measuring the absorbance of the trityl cation at $495 \mathrm{~nm}$, which in all cases were $98-100 \%$ for the commercial phosphoramidites, and $95-100 \%$ for the modified phosphoramidites. The final 5 -terminal DMT group in the oligonucleotides was retained for purification purposes. The final crude oligonucleotides on solid support were treated with $\mathrm{NH}_{3}\left(28 \%\right.$ in $\left.\mathrm{H}_{2} \mathrm{O}, 1 \mathrm{~mL}\right)$ at $55{ }^{\circ} \mathrm{C}$ for $16 \mathrm{~h}$. The mixture was filtered and the filtrate was evaporated to dryness at $45{ }^{\circ} \mathrm{C}$ by a steady $\mathrm{N}_{2}$ flow, and dissolved in an aqueous triethylammonium acetate buffer (500 $\mu \mathrm{L}, 0.05 \mathrm{M}, \mathrm{pH}$ 7.4). Analytically pure oligonucleotides were obtained by reversed-phase HPLC purification on a Waters 600 system using Xterra MS C18 $10 \mu \mathrm{m}(7.8 \times 50 \mathrm{~mm})$ columns and Xterra MS C18 $10 \mu \mathrm{m}(7.8 \times 10 \mathrm{~mm})$ precolumns. Elution was performed with $100 \%$ eluent A over $2 \mathrm{~min}$, followed by a linear gradient down to $30 \%$ eluent A over $38 \mathrm{~min}$, and then washed with $100 \%$ eluent B over $10 \mathrm{~min}$, and 100\% eluent A over $10 \mathrm{~min}$. (Eluent $\mathrm{A}=$ triethylammonium acetate
(0.05 M, pH 7.4). Eluent $\left.\mathrm{B}=75 \% \mathrm{MeCN} / \mathrm{H}_{2} \mathrm{O}(3: 1, \mathrm{v} / \mathrm{v})\right)$. The pure fractions were pooled and evaporated at $45{ }^{\circ} \mathrm{C}$. The 5 -terminal DMT group was removed by treatment with acetic acid $\left(80 \%\right.$ in $\left.\mathrm{H}_{2} \mathrm{O}, 100 \mu \mathrm{L}\right)$ for $30 \mathrm{~min}$, upon which an aqueous solution of NaOAc $(15 \mu \mathrm{L}, 3 \mathrm{M})$, an aqueous solution of $\mathrm{NaClO}_{4}(15 \mu \mathrm{L}, 5 \mathrm{M})$, and pure acetone $(1 \mathrm{~mL})$ were added. The oligonucleotides precipitated overnight at $-20{ }^{\circ} \mathrm{C}$. The supernatant was removed from the sedimented solid (centrifugation, $12000 \mathrm{rpm}, 10 \mathrm{~min}$ at $2^{\circ} \mathrm{C}$ ), and the remaining pellet was washed with cold acetone $(3 \times 1 \mathrm{~mL})$ and dissolved in $500 \mu \mathrm{L}$ pure water. Mass spectra of the oligonucleotides were recorded on a MALDI-TOF MS instrument in $\mathrm{ES}^{+}$mode. The concentrations of the purified oligonucleotides were determined by the optical density at $260 \mathrm{~nm}$, assuming that the molar absorptivities of the oligonucleotides equal the sum of each constituent nucleotide monomer. The extinction coefficients of the modified monomers in $\mathrm{mL} \mu \mathrm{mol}^{-1} \mathrm{~cm}^{-1}, \varepsilon_{260}(\mathbf{X})$ $=7.8, \varepsilon_{260}(\mathbf{Y})=5.8$ and $\varepsilon_{260}(\mathbf{Z})=5.2$, were determined from the slopes of the absorbance of the fully deprotected nucleosides at 25, 50, 75 and $100 \mu \mathrm{M}$ concentrations $\left(R^{2}>0.9995\right)$.

\section{Thermal denaturation experiments}

The duplex samples consisted of $1.5 \mu \mathrm{M}$ concentrations of each oligonucleotide in phosphate buffered saline solution (2.5 $\mathrm{mM} \mathrm{Na}_{2} \mathrm{HPO}_{4}, 5.0 \mathrm{mM} \mathrm{NaH} \mathrm{PO}_{4}, 100 \mathrm{mM} \mathrm{NaCl}, 0.1 \mathrm{mM}$ EDTA, pH 7). The strands were annealed by heating the sample to $80{ }^{\circ} \mathrm{C}$ followed by a slow cooling to $10{ }^{\circ} \mathrm{C}$. The increase in absorbance at $260 \mathrm{~nm}$ as a function of temperature from $10{ }^{\circ} \mathrm{C}$ to $75{ }^{\circ} \mathrm{C}\left(1{ }^{\circ} \mathrm{C} \mathrm{min}^{-1}\right)$ was recorded on a UV/Vis spectrometer using a Peltier Temperature Programmer. The listed $T_{\mathrm{m}}$ values were determined as the first-derivative maximum of the absorbance $v s$. temperature curves, and are averages of at least duplicate determinations that agreed with each other within $0.5^{\circ} \mathrm{C}$.

\section{Circular dichroism spectroscopy}

CD spectra were recorded on a Jasco J-715 spectropolarimeter as a digital average of 5 scans from 200-350 nm using a split width of $2.0 \mathrm{~nm}$ and a scan speed of $50 \mathrm{~nm} \mathrm{~min}{ }^{-1}$. The samples were prepared similarly to the samples used for the melting temperature studies with $1.5 \mu \mathrm{M}$ concentrations of each strand. Quartz optical cells with an optical path length of $5.0 \mathrm{~mm}$ were used.

\section{Molecular modelling}

The global minimum structures were found from 5 ns molecular dynamics simulations using the all-atom AMBER* force field applying the GB/SA continuum solvation model ${ }^{22}$ with extended cut-offs for non-bonded interactions (van der Waals $8 \AA$ and electrostatics $20 \AA$ ). Calculations were performed in MacroModel V10.4 (within Maestro V9.8.017). The hybrid duplexes were built in B-type helical geometries, and relaxed with AMBER*. Initial Monte Carlo torsional samplings (MCMM) were performed to generate 1000 structures, which were individually minimized into local minima. The lowest energy structure of each simulation was used for the sub- 
sequent MD simulations. The MD simulations were performed at $300 \mathrm{~K}$. The SHAKE all bonds to hydrogen setting was imposed in order to increase the time step to $2.2 \mathrm{fs}$, and an equilibrium time of 100 ps was used to stabilize the calculations. A multiple minimization of the 500 sample structures was performed to obtain a converged global minimum structure.

The torsional energy profiles were calculated on the geometry optimized structures (DFT/B3LYP/6-31G**) by a series of fully relaxed coordinate scans of the dihedral angles $\varphi$ and $\psi$. The bonds defining the $\varphi$ and $\psi$ dihedral angles are shown in Fig. 5. The computations were performed in MacroModel V10.4 using the OPLS-2005 force field ${ }^{21}$ applying the GB/SA solvation model. The torsional sampling was performed by $1^{\circ}$ increments of each of the dihedral angles (from $0^{\circ}$ to $360^{\circ}$ ) to obtain a total of 130321 structures per search. The collection of conformations was energy minimized by allowing all degrees of freedom except $\varphi$ and $\psi$ which were frozen, the relative energies of which were plotted in the $(\varphi, \psi)$ space using isoenergy contours at $2 \mathrm{~kJ} \mathrm{~mol}^{-1}$ intervals.

\section{Acknowledgements}

The research was supported by The Danish Council for Independent Research | Natural Sciences (FNU).

\section{Notes and references}

1 M. Ahmadian and D. E. Bergstrom, in Modified Nucleosides, ed. P. Herdewijn, Wiley-VCH Verlag GmbH \& Co. KGaA, 2008, pp. 249-276.

2 L. C. Sowers, B. R. Shaw and W. D. Sedwick, Biochem. Biophys. Res. Commun., 1987, 148, 790-794.

3 P. P. Seth and E. E. Swayze, in Natural Products in Medicinal Chemistry, ed. S. Hanessian, Wiley-VCH Verlag GmbH \& Co. KGaA, 2014, pp. 403-440.

4 (a) B. C. Froehler, S. Wadwani, T. J. Terhorst and S. R. Gerrard, Tetrahedron Lett., 1992, 33, 5307-5310; (b) J. Sági, A. Szemzö, K. Ébinger, A. Szabolcs, G. Sági, É. Ruff and L. Ötvös, Tetrahedron Lett., 1993, 34, 21912194; (c) T. W. Barnes and D. H. Turner, J. Am. Chem. Soc., 2001, 123, 4107-4118.

5 A. J. Gutierrez, T. J. Terhorst, M. D. Matteucci and B. C. Froehler, J. Am. Chem. Soc., 1994, 116, 5540-5544.

6 P. Kočalka, N. K. Andersen, F. Jensen and P. Nielsen, ChemBioChem, 2007, 8, 2106-2116.

7 (a) N. K. Andersen, N. Chandak, L. Brulíková, P. Kumar, M. D. Jensen, F. Jensen, P. K. Sharma and P. Nielsen, Bioorg. Med. Chem., 2010, 18, 4702-4710; (b) N. K. Andersen, H. Døssing, F. Jensen, B. Vester and P. Nielsen, J. Org. Chem., 2011, 76, 6177-6187.

8 M. E. Østergaard, P. Kumar, J. Nichols, A. Watt, P. K. Sharma, P. Nielsen and P. P. Seth, Nucleic Acid Ther., 2015, 25, 266-274.
9 M. J. Robins and P. J. Barr, Tetrahedron Lett., 1981, 22, 421424.

10 (a) C. W. Tornøe, C. Christensen and M. Meldal, J. Org. Chem., 2002, 67, 3057-3064; (b) V. V. Rostovtsev, L. G. Green, V. V. Fokin and K. B. Sharpless, Angew. Chem., Int. Ed., 2002, 41, 2596-2599.

11 (a) P. Kumar, N. Chandak, P. Nielsen and P. K. Sharma, Bioorg. Med. Chem., 2012, 20, 3843-3849; (b) P. Kumar, M. Hornum, L. J. Nielsen, G. Enderlin, N. K. Andersen, C. Len, G. Hervé, G. Sartori and P. Nielsen, J. Org. Chem., 2014, 79, 2854-2863.

12 (a) P. Yakovchuk, E. Protozanova and M. D. Frank-Kamenetskii, Nucleic Acids Res., 2006, 34, 564-574; (b) M. Petersheim and D. H. Turner, Biochemistry, 1983, 22, 256-263.

13 C. R. Martinez and B. L. Iverson, Chem. Sci., 2012, 3, 21912201.

14 (a) C. A. Hunter, J. Mol. Biol., 1993, 230, 1025-1054; (b) R. Luo, H. S. R. Gilson, M. J. Potter and M. K. Gilson, Biophys. J., 2001, 80, 140-148; (c) K. M. Guckian, B. A. Schweitzer, R. X.-F. Ren, C. J. Sheils, D. C. Tahmassebi and E. T. Kool, J. Am. Chem. Soc., 2000, 122, 2213-2222; (d) R. A. Friedman and B. Honig, Biophys. J., 1995, 69, 1528-1535.

15 D. J. Hurley and Y. Tor, J. Am. Chem. Soc., 1998, 120, 21942195.

16 K. Kutonova, M. Trusova, P. Postnikov, V. Filimonov and J. Parello, Synthesis, 2013, 2706-2710.

17 M. Hornum, P. Kumar, P. Podsiadly and P. Nielsen, J. Org. Chem., 2015, 9592-9602.

18 (a) L. Zhang, X. Chen, P. Xue, H. H. Y. Sun, I. D. Williams, K. B. Sharpless, V. V. Fokin and G. Jia, J. Am. Chem. Soc., 2005, 127, 15998-15999; (b) B. C. Boren, S. Narayan, L. K. Rasmussen, L. Zhang, H. Zhao, Z. Lin, G. Jia and V. V. Fokin, J. Am. Chem. Soc., 2008, 130, 8923-8930.

19 (a) U. Pradere, V. Roy, T. R. McBrayer, R. F. Schinazi and L. A. Agrofoglio, Tetrahedron, 2008, 64, 9044-9051; (b) A. Montagu, V. Roy, J. Balzarini, R. Snoeck, G. Andrei and L. A. Agrofoglio, Eur. J. Med. Chem., 2011, 46, 778-786.

20 G. R. Bishop and J. B. Chaires, in Curr. Protoc. Nucleic Acid Chem, ed. S. Beaucage, et al., 2003, ch. 7, unit 7.11.

21 J. L. Banks, H. S. Beard, Y. Cao, A. E. Cho, W. Damm, R. Farid, A. K. Felts, T. A. Halgren, D. T. Mainz, J. R. Maple, R. Murphy, D. M. Philipp, M. P. Repasky, L. Y. Zhang, B. J. Berne, R. A. Friesner, E. Gallicchio and R. M. Levy, J. Comput. Chem., 2005, 26, 1752-1780.

22 D. Qiu, P. S. Shenkin, F. P. Hollinger and W. C. Still, J. Phys. Chem. A, 1997, 101, 3005-3014.

23 G. F. Deleavey and M. J. Damha, Chem. Biol., 2012, 19, 937954.

24 (a) A. A. Koshkin, S. K. Singh, P. Nielsen, V. K. Rajwanshi, R. Kumar, M. Meldgaard, C. E. Olsen and J. Wengel, Tetrahedron, 1998, 54, 3607-3630; (b) S. Obika, D. Nanbu, Y. Hari, K. Morio, Y. In, T. Ishida and T. Imanishi, Tetrahedron Lett., 1997, 38, 8735-8738. 
25 (a) T. Y. Shen, Angew. Chem., Int. Ed., 1970, 9, 678-688; (b) P. Kielkowski, R. Pohl and M. Hocek, J. Org. Chem., 2011, 76, 3457-3462; (c) P. Kielkowskia, H. Cahováa, R. Pohla and M. Hocek, Bioorg. Med. Chem., 2016, 24, 1268-1276.

26 (a) P. Kumar, A. F. Sorinas, L. J. Nielsen, M. Slot, K. Skytte, A. Nielsen, M. Dalager, P. K. Sharma, B. Vester, M. Petersen and P. Nielsen, J. Org. Chem., 2014, 79, 8020-8030; (b) M. Dalager, N. K. Andersen, P. Kumar, P. Nielsen and
P. K. Sharma, Org. Biomol. Chem., 2015, 13, 7040-7049; (c) P. Kumar, P. K. Sharma, J. Hansen, L. Jedinak, C. Reslow-Jacobsen, M. Hornum and P. Nielsen, Bioorg. Med. Chem., 2016, 24, 742-749.

27 (a) K. M. Guckian, B. A. Schweitzer, R. X.-F. Ren, C. J. Sheils, P. L. Paris, D. C. Tahmassebi and E. T. Kool, J. Am. Chem. Soc., 1996, 118, 8182-8183; (b) T. W. Kim and E. T. Kool, J. Org. Chem., 2005, 70, 2048-2053. 